Summer 2005

\title{
Reconciling with the Past: John Willis and the Question of Judicial Review in Inter-War and Post- War England
}

Peter Lindseth

University of Connecticut School of Law

Follow this and additional works at: https://opencommons.uconn.edu/law_papers

\section{Recommended Citation}

Lindseth, Peter, "Reconciling with the Past: John Willis and the Question of Judicial Review in Inter-War and Post-War England" (2005). Faculty Articles and Papers. 259.

https://opencommons.uconn.edu/law_papers/259 


\section{HEINONLINE}

Citation: 55 U. Toronto L.J. 6572005

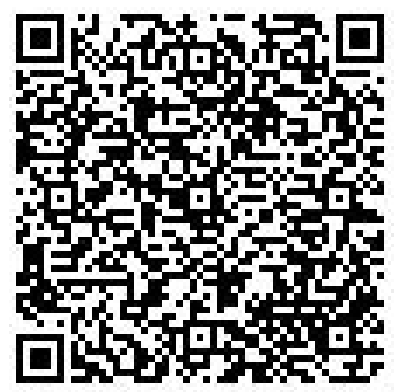

Content downloaded/printed from

HeinOnline (http://heinonline.org)

Mon Aug 15 18:11:04 2016

-- Your use of this HeinOnline PDF indicates your acceptance of HeinOnline's Terms and Conditions of the license agreement available at http://heinonline.org/HOL/License

-- The search text of this PDF is generated from uncorrected OCR text.

-- To obtain permission to use this article beyond the scope of your HeinOnline license, please use:

https://www.copyright.com/ccc/basicSearch.do?

\&operation $=$ go\&search Type $=0$

\&lastSearch $=$ simple\&all $=$ on\&titleOrStd $N o=1710-1174$ 
JOHN WILLIS AND THE QUESTION OF JUDICIAL REVIEW IN INTER-WAR AND POST-WAR ENGLAND ${ }^{\dagger}$

\section{Introduction: The 'problem of reconciling'}

John Willis's 1933 classic, The Parliamentary Powers of the English Government Departments, is essential reading to any historian interested in the debates over legislative delegation and administrative justice in inter-war England. ${ }^{1}$ The book's immediate purpose was to respond to the assertions made by Lord Hewart, the Lord Chief Justice of England, in his notorious polemic, The New Despotism, published in $1929 .{ }^{2}$ Hewart argued, very much in a Diceyan vein, that the emergent administrative state was a perversion of the most venerable principles of the English constitution, notably parliamentary sovereignty and the 'Rule of Law' as enforced by the ordinary common law courts. Hewart asserted that, particularly during and after World War I, Parliament was using its undisputed sovereignty to make wholesale shifts of legislative authority outside the parliamentary realm and then, through a variety of statutory mechanisms, to deprive the ordinary courts of their rightful jurisdiction over the lawful exercise of that authority. The effect was to undermine the rule of law that had been a cornerstone of the English constitution since the seventeenth century.

In Parliamentary Powers, Willis counters that the administrative state in England has a historical pedigree and underlying normative justification of its own, one very different from the Diceyan constitutionalism of Hewart. Administrative structures did not suddenly emerge during World War I or after; rather, they were the product of '[a] long period of imperceptible growth' in the nineteenth century, which was followed in the early twentieth century by 'a quickening to meet the needs of the new Social State' and then by 'a sudden flowering during the War, and after the War the full fruition.... ${ }^{3}$ The method that Parliament 'invariably

* Associate Professor of Law, University of Connecticut School of Law.

$\dagger$ I want to thank all the participants of the Willis Conference at the University of Toronto Faculty of Law for two days of excellent discussion about the modern administrative state - its past, present, and future. It was a worthy tribute to John Willis.

1 John Willis, The Parliamentary Powers of English Government Departments (Cambridge: Harvard University Press, 1933) [Parliamentary Powers].

2 Lord Hewart of Bury, The New Despotism (London: Emest Benn, 1929).

3 Willis, Parliamentary Powers at 5 . The definitive modern discussion of this history is to be found in H.W. Arthurs, 'Without the Law': Administrative Justice and Legal Pluralism in 
followed' in delegating legislative and adjudicative powers to the government departments was, according to Willis, functionalist: Parliament viewed the task of apportioning power as 'neither one of law nor of formal logic, but of expediency. ${ }^{, 4}$ Parliament assigned authority 'to the body which experience has shown best fitted to perform the work' in question. ${ }^{5}$ Little or no regard was given to whether this allocation of authority transgressed traditional constitutional boundaries between legislative, executive, and judicial powers.

In analysing the modern administrative state from a functionalist perspective, the young Willis associated himself with a broader scholarly movement in inter-war England (whose leaders included Harold Laski, William Robson, and Ivor Jennings) that had assembled to counter attacks on administrative governance from the bench ${ }^{6}$ Functionalists set out to explain and justify the modern administrative state to a sometimes sceptical English public, while also noting that the public's demands for greater state intervention had given rise to the functionalist expansion of administrative structures in the first place. ${ }^{7}$ The appearance of Parliamentary Powers simply marked the entry of a new and vigorous voice into this highly charged legal-political discussion. However, soon after the book appeared, Willis was (as Michael Taggart so nicely puts it in his contribution to this volume) 'lost to England. ${ }^{8}$ Following the two-year research stint at Harvard during which he completed Parliamentary Powers (under the supervision of Felix Frankfurter), a variety of circumstances took Willis to Canada and kept him there for the rest of his life. Canadian public law scholarship was, of course, all the richer for it (as is fittingly commemorated by this volume and the conference that gave rise to it).

Nineteenth-Century England (Toronto: University of Toronto Press, 1985), specifically at c. 4 ('The New Administrative Technology: Necessity, Invention, and Legal Centralism') and c. 5 ('The Emergence of Administrative Law: The New Pluralism').

4 See John Willis, 'Three Approaches to Administrative Law: The Judicial, the Conceptual, and the Functional' (1935) 1 U.T.L.J. 53 at 75 ['Three Approaches'].

5 Ibid.

6 Martin Loughlin superbly analyzes this functionalist style of legal analysis, as well as its intellectual-historical underpinnings, in his Public Law and Political Theory (Oxford: Clarendon Press, 1992) at 165-73.

7 The report of the Committee on Ministers' Powers captures this position: 'The truth is that if Parliament were not willing to delegate law-making power, Parliament would be unable to pass the kind and quantity of legislation which modern public opinion requires.' Report of the Committee on Ministers' Powers, Cmd. 4060 (London: HMSO, 1932) at 23. This statement could have applied equally well to the French and German parliaments of the same period. See generally Peter $\mathbf{L}$. Lindseth, 'The Paradox of Parliamentary Supremacy: Delegation, Democracy, and Dictatorship in Germany and France, 1920s-1950s' (2004) 113 Yale L.J. 1341 ['Paradox'].

8 Michael Taggart, 'From "Parliamentary Powers" to Privatization: The Chequered History of Delegated Legislation in the Twentieth Century' (2005) 55 U.T.L.J. 575 at 593. 
But as Martin Loughlin remarked at the conference, it is impossible to understand Willis without recognizing that he remained, first and foremost, 'an Englishman' throughout his life. Willis may have been 'lost to England' by his move to Canada, but England was certainly not lost to Willis, at least not in a scholarly sense. His writings in Canada reflect an abiding interest in English developments; ${ }^{9}$ indeed, Willis's repeated reference to English cases, statutes, committee reports, and scholarship suggests that England continued to serve as his analytical baseline for examining the interaction of administrative governance and parliamentary democracy more generally, whether in Canada or elsewhere in the Commonwealth.

The debates in inter-war England engendered by The New Despotism, followed by the issuance of the report of the Committee on Ministers' Powers of 1932 (which was formed specifically in response to Hewart's attack),${ }^{10}$ would leave their mark on Willis's outlook for the remainder of his career. One need only look at his closing salvo in 'Lawyers' Values and Civil Servants' Values,' directed at the McRuer Report, in 1968: there Willis admits that his was an 'ill-tempered comment, reminiscent of the less illuminating disputes of the thirties. ${ }^{11}$ The McRuer Report was, from Willis's perspective, the ghost of The New Despotism raising its ugly head once again, albeit in a somewhat more muted, Canadian form. He explains (if not necessarily excusing himself - he probably felt little need for excuse) that his ill temper was 'brought on by a recommendation characteristic of the "establishment side" in the thirties. ${ }^{.2}$ Reflecting on McRuer's call for expanded judicial review of administrative action in Ontario, Willis asserts - somewhat sarcastically - that 'the Commission might just as well go the whole hog and recommend that all the deciding authorities of whatever nature be brought within the ordinary court

9 In addition to 'Three Approaches,' supra note 4, see, e.g., John Willis, 'Delegation of Legislative and Judicial Powers to Administrative Bodies: A Study of the Report of the Committee on Ministers' Powers' (1932) 18 Iowa L.Rev. 150 ['Delegation']; John Willis, Book Review of Cabinet Government by W. Ivor Jennings (1937) 15 Can.Bar Rev. 579 [Review of Jennings, Cabinet Government]; John Willis, 'Statutory Interpretation in a Nutshell' (1938) 16 Can.Bar Rev. 1 ['Nutshell']; John Willis, Book Review of Freedom Under the Law by Sir Alfred Denning (1949) 8 U.T.L.J. 414 [Review of Denning, Freedom]; John Willis, 'The Administrator as Judge - The Citizen's Right to an Impartial Tribunal' (1957) 5 U.B.C.Leg. Notes 427 ['Administrator as Judge']; John Willis, 'Administrative Decision and the Law: The Canadian Implications of the Franks Report' (1959) 13 U.TL.J. 45 ['Canadian Implications']; John Willis, 'The McRuer Report: Lawyers' Values and Civil Servants' Values' (1968) 18 U.T.L.J. 351 ['Lawyers' Values']; and John Willis, 'Canadian Administrative Law in Retrospect' (1974) 24 U.T.L.J. 225 ['Retrospect'].

10 Report of the Committee on Ministers' Powers, supra note 7.

11 Willis, 'Lawyers' Values,' supra note 9 at 360.

12 Ibid. 
system. ${ }^{13}$ All this, of course, would negate the very purpose of delegation in the first place - ' $\mathrm{e}] \mathrm{xpertise,} \mathrm{avoidance} \mathrm{of} \mathrm{delay,} \mathrm{reduction} \mathrm{of} \mathrm{expense} \mathrm{I}^{\prime 14}$ - but this was the slippery slope that Willis believed Ontario administrative law threatened to descend if the McRuer recommendations were followed.

The irony is that, as David Mullan shows in his contribution to this volume, there was in fact a good deal of common ground between Willis and the McRuer Report on numerous critical points. ${ }^{15}$ This common ground, however, is not my principal concern here. Rather, I am more interested in how Willis's perspective on judicial review in the modern administrative state - Canadian or otherwise - reflected an attachment to the battle lines first traced in England in the 1920s and 1930s and then carried over into the post-war decades. This preoccupation with old debates gave Willis's subsequent work a sometimes anachronistic tone, as he himself admitted in 'Canadian Administrative Law in Retrospect' in 1974. There he recognized that he had always remained 'one of those belligerent academics of the thirties' who was ever ready to challenge any 'regression ... to the belligerent anti-bureaucratic lawyers' attitudes of those days. ${ }^{, 16}$ (Apparently there was plenty of belligerence to go around then.)

Although Willis's ire was usually directed at the holders of these 'antibureaucratic' attitudes (along with their 'theological' approach to administrative law), ${ }^{17}$ his real concern was arguably with a more elusive opponent. He referred to this adversary as the 'feeling of the average individual citizen which, I think, lies at the root of the constitutional principle known as the "Rule of Law." ${ }^{18}$ Willis puzzled throughout his career over the way in which popular opinion persistently and, in his view, uncritically equated the rule of law with judicial review. He saw this linkage as perhaps the greatest obstacle to the realization of his ideal system of discretionary control, in which policies made by civil servants would be, to the broadest extent possible, insulated from oversight by the ordinary courts. In 1937 Willis spoke of legal-cultural attachments of this kind as among the "unrealities which provide not only a living for a large and respectable profession but articles of faith for the whole of AngloAmerican society and must, accordingly, rank as a reality by prescription, and so, alas, at present ineradicable. ${ }^{19}$ And nearly four decades later he

13 Ibid.

14 Ibid.

15 David J. Mullan, 'Willis v. McRuer: A Long-Overdue Replay with the Possibility of a Penalty Shoot-Out' (2005) 55 U.T.L.J. 535.

16 Willis, 'Retrospect,' supra note 9 at 234.

17 Ibid. at 227-9.

18 Willis, 'Administrator as Judge,' supra note 9 at 428.

19 Willis, Review of Jennings, Cabinet Government, supra note 9 at 581. 
lamented that so long as 'most people seem to think' that an ordinary court is " $[w]$ here you get "justice" and [that] all you get from an administrative tribunal is "second-rate justice" ..., no amount of patient argument by "pointy-headed perfessers" [sic] will confine judicial review to ... its correct limits. ${ }^{20}$

Remarks like these reflect Willis's persistent frustration with the role of judicial review in the administrative state. On the one hand, policymaking structures had consistently moved in a direction Willis applauded (responding, as they were, to the 'functional' demands for effective regulation and state intervention in a complex industrial society). On the other hand, the evolution of these structures was continually impeded by historical conceptions of legitimacy that Willis either lamented (witness his constant attacks on the 'eighteenth-century constitution' that gripped the minds of lawyers and judges 'steeped in the common law') ${ }^{21}$ or accepted grudgingly (as when he acknowledged that 'there is much good to be said' of 'the currency of constitutional belief like the "separation of powers" or the "rule of law"'). ${ }^{22}$

These attachments to conceptions of legitimacy inherited from the past were responsible, in Willis's estimation, for the misguided focus of English administrative law on 'the problem of reconciling,' as he called it. ${ }^{23}$ This term refers to the adjustments needed both in structures of governance and in public law so that, on the one hand, effective state intervention could proceed but, on the other, it could still be understood as 'constitutional' and 'democratic' in a historically recognizable sense. This quest for reconciliation in turn led, in Willis's view, to an unnecessary emphasis in administrative law on burdensome 'controls' and 'safeguards' - most importantly, judicial review - something that Willis critiqued throughout his career, from his analysis of the Report of the Committee on Ministers' Powers in $1932^{24}$ to his 'irritated dissent' from the Report of the McRuer Commission in $1968 .{ }^{25}$

This article views Willis's discomfort with the 'problem of reconciling' as itself deeply problematic. His disparaging attitude towards the place of judicial review in the administrative state was an outgrowth of a limited and one-sided conception of historical change that focused on structural evolution while, in effect, dismissing its cultural dimension except as a force of obstruction and resistance. Willis rejected any attempt at 'reconciling' as a fundamentally misguided effort at 'seeing likeness in unlike

20 Willis, 'Retrospect,' supra note 9 at 244.

21 Willis, 'Lawyers' Values,' supra note 9 at 353.

22 Willis, 'Three Approaches,' supra note 4 at 70.

23 Ibid.

24 Willis, 'Delegation,' supra note 9, critiquing Report of the Committee on Ministers' Powers, supra note 7.

25 Willis, 'Lawyers' Values,' supra note 9 at 351. 
things. ${ }^{26}$ In fact, 'seeing likeness in unlike things' is an inescapable fact of life. ${ }^{27}$ Historical change is not simply a function of shifts in economic or legal structures; rather, it also depends on how these shifts are 'experienced in social and cultural life,' to borrow a phrase from E.P. Thompson. ${ }^{28}$ Willis's long career as an active scholar - roughly from the 1930s to the late 1960s and early 1970s - spanned a period of intense historical dialectic in English administrative law, in which functionally evolving structures of governance were necessarily 'experienced' in relation to historically rooted ideas and values of legitimate constitutionalism that depended, in important respects, on the continued existence of some form of judicial review. This 'experience,' in turn, motivated political and legal efforts to 'reconcile' the new structures with ideas of legitimacy inherited from the past.

Part II of this article summarizes the debates over legislative delegation and administrative justice in inter-war England to give a sense not only of the intensity of this dialectic but also of the legal-political environment in which Willis came of age as a scholar. Part III turns to the two decades after 1945 to examine efforts by legal and political actors in England to arrive at a more or less stable settlement over the role of judicial review in the administrative state. This settlement would build on four decades of learning about the place of the courts - or, dare I say, the 'function' of the courts - in the panoply of mechanisms designed to control and supervise administrative discretion. The passage of the Tribunals and Inquiries Act of $1958^{29}$ marked the key turning point, after which the task would become, in some sense, 'sub-constitutional,' shifting to the development of substantive administrative law within the confines of the constitutional settlement that emerged out of the debates of the middle third of the twentieth century.

26 Review of Jennings, Cabinet Government, supra note 9 at 581 .

27 Cf. Sarah Hanley, 'Engendering the State: Family Formation and State-Building in Early Modern France' (1989) 16 French Historical Studies 4 at 5-6 (describing 'the historical process as a renewable dialogue or cultural conversation, wherein history is culturally ordered by existing concepts, or schemes of meaning, at play in given times and places; and culture is historically ordered when schemes of meaning are revalued and revised as persons act and reenact them over time. One might regard this process of reordering as one that "counterfeits culture"; that is, as a process that replicates the perceived original but at the same time (consciously or unconsciously) forges something quite new.').

28 ' $[\mathrm{H}]$ istorical change eventuates,' as E.P. Thompson once wrote, because changes in material structures 'are experienced in social and cultural life, refracted in men's ideas and their values, and argued through their actions, their choices and their beliefs.' E.P. Thompson, 'History and Anthropology, Lecture Given at the Indian History Congress (Dec. 30, 1976)' in E.P. Thompson, Making History: Writings on History and Culture (New York: New Press/Norton, 1994) 200 at 222 ['History and Anthropology'].

296 Eliz. 2, c. 66. 
Willis viewed this process with sustained interest, even if from afar, and he seems rarely to have missed an opportunity to relate the English and Canadian developments where possible. This article concludes, then, by reflecting on the writings of Willis at the end of his career in light of efforts in post-war England to achieve a constitutional settlement over the place of judicial review in administrative law.

\section{The debate over delegation and administrative justice in inter-war England}

Lord Hewart's infamous 1929 diatribe, The New Despotism, argued that delegation of legislative and adjudicative powers to the executive posed a grave threat to 'the two leading features' of the English constitution, 'the Sovereignty of Parliament and the Rule of Law. ${ }^{30}$ Delegation to the executive was, in Hewart's estimation, 'an ingenious and adventurous' way 'to employ the one to defeat the other. ${ }^{, 31}$ The title of the book, of course, was meant to bring to mind the political conflicts of the seventeenth century that culminated in the revolution of 1688, destroying the 'old despotism' and definitively establishing parliamentary sovereignty as the central organizing principle of the English constitution. Bound up in this triumph was a related development: the defeat of the crown's claimed monopoly to adjudicate administrative disputes, akin to what the French monarchy had successfully established during the same period (and which would provide the foundation of the autonomous French system of administrative justice that persists to this day).$^{32}$

The revolutionary settlement that modern England inherited from the seventeenth century thus involved 'a double control of government activity: control of legality in the courts and political control in Parlia-

30 Hewart, The New Despotism, supra note 2 at 17.

31 Ibid.

32 In France a royal edict of 1641 would prohibit ordinary judicial courts from reviewing any matter 'which may concern the state, administration or government' (the Edict of Saint-Germain of February 1641). In the same year, the English Parliament abolished the Court of Star Chamber; it later abolished the remainder of the jurisdictions under the control of the Privy Council in 1688. Thus, as the French monarchy was hardening the division between administrative and ordinary justice in pursuit of the 'general interest' of the state, the English Parliament's abolition of the conciliar courts meant 'the unchallenged dominance of the ordinary courts, the courts of common law' (J.D.B. Mitchell, 'The Causes and Consequences of the Absence of a System of Public Law in the United Kingdom' [1965] Pub.L. 95 at 97 ['Causes and Consequences']), within which the concept of private property, and not the 'general interest,' would be the guiding principle. For a more detailed discussion of the French experience, see Peter Lindseth, "Always Embedded" Administration: The Historical Evolution of Administrative Justice as an Aspect of Modern Governance' in Christian Joerges, Bo Stråth, \& Peter Wagner, eds., The Economy as a Polity: the Political Constitution of Contemporary Capitalism (London: UCL Press, forthcoming) ['Always Embedded']. 
ment. ${ }^{33}$ It was this seeming 'separation of powers,' and, in particular, the separation of executive and adjudicative power, that Montesquieu had celebrated as the central feature of the English constitution in De l'esprit des lois in $1748 .^{34}$ During the nineteenth century, however, questions began to be raised as to how well Montesquieu's construct actually corresponded to the English reality. As F.W. Maitland would note just a century after Montesquieu, 'It is curious that some political theorists should have seen their favourite ideal, a complete separation of administration from judicature, realised in England; in England, in all places in the world, where the two have for ages been inextricably blended. The mistake,' Maitland continues, 'comes from looking just at the surface and the showy parts of the constitution. ${ }^{35}$ The deeper constitutional reality despite the seeming achievements of 1688 - was that administrative officers in England, in executing their legislatively appointed authority, continued to make inquiries and render judgment on particular sets of facts in light of general legal norms - in other words, to adjudicate in everything but name - often without appeal to the ordinary courts. As Willis himself aptly summarized in 1932, 'No amount of Montesquieu and Dicey could blind students of practical government to the obvious fact that the government departments have long been permitted by statute to exercise powers of legislation and a judicial decision delegated to them by Parliament. ${ }^{, 36}$

As William Robson would show in his seminal 1928 monograph, Justice and Administrative Law, this form of administrative adjudication became even more prominent ' $[\mathrm{w}]$ ith the extension, during the nineteenth and twentieth centuries, of the functions of government to one new field after another. ${ }^{, 37}$ This gave rise, Robson asserts, to 'a need for a technique of adjudication better fitted to respond to the social requirements of the time than the elaborate and costly system of enforcement provided by litigation in the courts of law. ${ }^{38}$ In England, as elsewhere, adjudication of administrative disputes required the interpretation of the regulatory norms produced in the administrative sphere in pursuance of Parlia-

33 Mitchell, 'Causes and Consequences,' supra note 32 at 98.

34 Charles Louis de Secondat, baron de Montesquieu, De l'esprit des loix ..., 2 vols. (Genève, 1748); De l'esprit des lois, 2 vols. (Paris: Flammarion, 1979), livre XI, c. VI, 'De la Constitution d'Angleterre,' vol. 1 at 294-5; see also livre VI, c. VI, 'Que, dans la monarchie, les ministres ne doivent pas juger,' vol. 1 at 207-8.

35 Frederic William Maitland, 'The Shallows and Silences of Real Life' (1888) in The Collected Papers of Frederic William Maitland: Dowming Professor of the Laws of England, vol. 1 (Cambridge: Cambridge University Press, 1911) at 478, quoted in William A. Robson, Justice and Administrative Law: A Study of the British Constitution (London: Macmillan, 1928) at 26.

36 Willis, 'Delegation,' supra note 9 at 151 .

37 Robson, Justice and Administrative Law, supra note 35 at 32.

38 Ibid. 
ment's legislative mandate. ${ }^{39}$ Moreover, this case-by-case interpretation of regulatory norms necessarily shaped the enabling legislation's effective content by filling in gaps or clarifying the meaning of vague terms. In this sense, administrative adjudication was intimately bound up with the political purposes of the enabling legislation itself, as well as with the regulatory scheme it established. ${ }^{40}$ Administrative adjudication served as a kind of 'commitment mechanism' (to use more modern game-theoretical language ${ }^{41}$ to ensure that the purposes of that scheme would be not be sacrificed in the resolution of particularist disputes over implementation. And thus, as state intervention into economic and social affairs grew over the course of the nineteenth century in England, adjudicative powers were increasingly conferred on officials or tribunals that were not classically 'judicial' in nature but, rather, were a part of the administrative hierarchy, at the summit of which was a departmental minister responsible before Parliament.

Judicial criticisms of ministerial power in the inter-war period, like that of Lord Hewart, thus came after nearly a century of deterioration in the constitutional position of the ordinary courts relative to ministerial power, a process that was largely incremental and therefore went unnoticed and uncontested until the early twentieth century. ${ }^{42}$ While it would be wrong to say that the result was an autonomous 'system' of administrative justice akin to what France developed over the eighteenth and nineteenth centuries (with a supreme administrative court - the Conseil d'état - sitting atop a hierarchy of subordinate administrative tribunals), there was nevertheless a kind of convergence with the French experience, in which a whole range of administrative conduct affecting the rights of private interests was excluded from the jurisdiction of the ordinary courts. ${ }^{43}$ The adjudicative decisions of English administrative officials were sometimes, but not necessarily, subject to judicial review; the extent of review depended on the regulatory domain and the provi-

39 An example is the Poor Law Board established under the Poor Law Amendment Act, 1834, 3 \& 4 Will. IV, c. 103. For a general discussion, see Cecil T. Carr, Concerning English Administrative Law (New York: Columbia University Press, 1941) at 4-6.

40 As Willis would later write, administrative adjudication involves an agency or board 'working out its bus system policy, its securities selling policy.' Willis, 'Administrator as Judge,' supra note 9 at 434 .

41 See Lindseth, 'Paradox,' supra note 7.

42 On the expansion of delegated legislative and adjudicative powers in England, see Carr, Concerming English Administrative Law, supra note 39 at, c. 1, 'The Eighteen-Thirties and After.' For legislative power, see also Cecil T. Carr, Delegated Legislation (Cambridge: Cambridge University Press, 1921), as well as Willis, Parliamentary Powers, supra note 1; and for adjudicative power in England, see also Robson, Justice and Administrative Law, supra note 35 .

43 See generally Lindseth, 'Always Embedded,' supra note 32. 
sions of the governing legislation. ${ }^{44}$ It was the judges' increasing realization of this state of affairs in the 1920s - 'a growing consciousness that governmental organization no longer squared with legal theory,' as Willis puts it in Parliamentary Powers ${ }^{45}$ - that led to the intense criticisms of ministerial powers from the bench.

The persistence of the notion that England lived under a system of a strict separation of powers, as well as its corollary - the 'Rule of Law' - as enforced by the ordinary courts, was of course due to the extraordinary influence on the legal profession of Dicey's Law of the Constitution, published first in $1885 .{ }^{46}$ Felix Frankfurter, observing the situation from the American perspective in 1936, described Dicey's book as an 'instance of sociological error surviving through charm and style, and of the aesthetic appeal of a magnificently simple generalization.' ${ }^{47}$ Dicey's generalization had two principal elements: first, that the powers of the crown in England 'must be exercised in accordance with ordinary common law principles which govern the relation of one Englishman to another'; ${ }^{48}$ and, second, that the very idea of a separate body of principles governing public action - a droit administratif - was 'absolutely foreign to English law,' because by definition the elaboration of such principles does 'not lie within the jurisdiction of the ordinary courts. ${ }^{49}$ For Dicey, ' $[t]$ his essential difference' - the exercise of adjudicative power by anything other than a judicial court - 'render[ed] the identification of droit administratif with any branch of English law an impossibility. ${ }^{50}$

By the end of Dicey's long career, however, even he could not ignore the weight of the evidence that a form of autonomous administrative law was in fact emerging in England, its development taking place largely outside the jurisdiction of the common law courts. ${ }^{51}$ This realization, published in 1915, did not mean that other lawyers raised on his orthodox teachings were ready to arrive that the same conclusion. Lord Chief

44 On the extraordinary variety of adjudicative procedures in the British administrative state in the early twentieth century, see generally Robson, Justice and Administrative Law, supra note 35 at c. III. See also Memoranda Submitted by Government Departments in Reply to Questionnaire of November 1929 and Minutes of Evidence taken before the Committee on Ministers' Powers (London: HMSO, 1932) [Memoranda Submitted].

45 Willis, Parliamentary Powers, supra note 1 at 29.

.46 A.V. Dicey, An Introduction to the Siudy of the Law of the Constitution (1885), 10th ed. (London: Macmillan, 1959) [Law of the Constitution].

47 Felix Frankfurter, 'Foreword' in W. Ivor Jennings, 'Courts and Administrative Law The Experience of English Housing Legislation' (1936) 49 Harv.L.Rev. 426 ['Courts and Administrative Law'].

48 Dicey, Law of the Constitution, supra note 46 at 387.

49 Ibid. at 388.

50 Ibid.

51 A.V. Dicey, 'The Development of Administrative Law in England' (1915) 31 L.Q.Rev. 148. See also W.J.L. Ambrose, 'The New Judiciary' (1910) 26 L.Q.Rev. 203. 
Justice Hewart himself, speaking to the American Bar Association in 1927, continued to assert that the common law did 'not recognize any droit administratif. Every person, whatever position he might occupy within the State, is subject to the law of the land, and there are no special tribunals for the trial of matters in which public departments or Ministers of State are concerned. ${ }^{52}$ Perhaps Hewart's own uncomfortable realization that this beloved maxim was no longer valid was the thing that prompted him to write what might still lay claim to being the most famous (or perhaps infamous) book in the history of English administrative law in the early twentieth century. What the modern advocates of executive power were trying to pass off as an emergent English system of 'administrative law' à la française, Hewart asserted, was a system of 'administrative lawlessness' characterized by an absence of procedural protections and rights of appeal to the judicial courts. ${ }^{53}$

The sudden intensification of criticism directed at administrative justice in England in the late 1920s (of which The New Despotism, as John Willis notes in Parliamentary Powers, was merely the most prominent example $)^{54}$ resulted, one could argue, from the ever larger encroachment by the administrative sphere into the core province of the ordinary courts - the protection of the rights of private property as guaranteed at common law. ${ }^{55}$ English housing law litigation was seen as the best example of the conflict between the mindset of the judicial courts and the interventionist aims of the new administrative state in Britain. ${ }^{56}$ Modern housing legislation interfered with common law rights of property owners (notably the freedom of contract) in any number of ways, imposing duties of repair and obligating landlords to conform to a whole range of standards, even, indeed, to transfer their property to the local authorities. More importantly, the prevailing statutes conferred a whole range of

52 The Times, 2 September 1927 and 30 September 1927, quoted in Robson, Justice and Administrative Law, supra note 35 at 30 .

53 See generally Hewart, The New Despotism, supra note 2 at c. IV.

54 For a succinct summary, see Willis, Parliamentary Powers, supra note 1 at 39-40. See also Carleton KempAllen, Bureaucracy Triumphant (London: Oxford University Press, 1931); Chih-Mai Chen, Parliamentary Opinion of Delegated Legislation (PhD dissertation, Columbia University, 1933). As Harold Laski would put it twenty years later, 'An irresponsible Lord Chief Justice, like Lord Hewart, and an academic lawyer whose hatred of change is even greater than his persuasive rhetoric, like Dr C.K. Allen, are only the best known names in a dramatic rearguard action that has been fought for many years now against a phantom army of bureaucrats lusting for power...' Harold J. Laski, Reflections on the Constitution (Manchester: Manchester University Press, 1951) at 42.

55 Jennings, 'Courts and Administrative Law,' supra note 47 at $443-4$.

56 See generally John Griffith, Judicial Politics since 1920: A Chronicle (Oxford: Blackwell, 1993) at 18-24 [Judicial Politics]. The second and third editions (1947 and 1951 respectively) of Robson, Justice and Administrative Law, supra note 35, also recount this history in detail. 
legislative and adjudicative powers on local officials, 'sometimes with and sometimes without the consent of the Minister of Health, and sometimes with and sometimes without an appeal to the courts. ${ }^{57}$

Statutory interpretation, particularly with regard to housing legislation, was also a terrain for contentious legal battles between courts and government departments, as well as other increasingly powerful administrative authorities. Most famously, there was the basic question of the reviewability of delegated legislation: although executive acts were, in the English tradition, presumptively reviewable, the doctrine of parliamentary supremacy left open the possibility that Parliament could choose, through privative clauses and other devices, to place delegated legislation beyond the judicial control of the ordinary courts. ${ }^{58}$ It was a matter of interpreting the language in the particular enabling act in question. In this regard, the courts had a good deal of difficulty with statutes that provided that subordinate legislative measures should 'have effect as if enacted in this Act. ${ }^{59}$ In 1894 , at a time when the powers of administrative bodies were less controversial in England, the House of Lords interpreted such language as precluding judicial review of the subordinate legislation at issue, in effect conferring on the resulting ministerial rules and orders the constitutional status of the statute itself. ${ }^{60}$ The 1894 decision turned, in large measure, on the doctrine of parliamentary control over the department in question, stressing that the subordinate legislation had to be 'laid before' Parliament and hence that Parliament had 'full control. ${ }^{, 61}$

In 1931, however, the House of Lords overruled this earlier holding in its famous decision in the Yaffe case. ${ }^{62}$ At issue was the meaning of s. 40(5) of the Housing Act of $1925,{ }^{63}$ which provided that an order of the Minister of Health confirming a housing scheme of a local authority 'shall have effect as if enacted in this Act.' Lord Hewart had singled out this provision as one among many he regarded as an excessive delegation to the executive.$^{64}$ The Minister of Health, in opposition to a judicial application by property owners to quash an order confirming a housing

57 Jennings, 'Courts and Administrative Law,' supra note 47 at 437.

58 Carr, Concerning English Administrative Law, supra note 39 at 47.

59 For an overview, including list of examples, see Willis, Parliamentary Powers, supra note 1 at 23-4.

60 Institute of Patent Agents v. Lockwood, [1894] A.C. 347 [Lockwood].

61 Mitchell, 'Causes and Consequences,' supra note 32 at 101, quoting the opinion of Lord Herschell in Lockwood ("it must be remembered that it" [scil: a wide discretionary power of legislating] "is committed to a public department, and a public department largely under the control of Parliament itself"').

62 Minister of Health $v$. The King (on the Prosecution of Yaffe), [1931] A.C. 494.

$6315 \& 16$ Geo. 5 , c. 14.

64 Hewart, The New Despotism, supra note 2 at 246. For his long list of other examples, see ibid. at c. X. 
scheme, argued that the court was powerless to review this decision in light of s. 40(5). The Divisional Court agreed ${ }^{65}$ but the Court of Appeal reversed, ${ }^{66}$ with one appellate judge calling s. 40(5) a 'kind of Star Chamber clause' that, if interpreted in favour of the Minister's position, would allow those exercising delegated legislative power 'to contravene [legislatively mandated] conditions, and make ultra vires orders which cannot be controlled by the Courts which have to administer the laws of the land. ${ }^{67}$ The House of Lords affirmed the Court of Appeal on the interpretation of s. $40(5)$ but, on the merits, held that the housing scheme approved by the minister was valid. ${ }^{68}$

For supporters, the decision of the House of Lords obviated the need for any more ' $[j]$ udicial ingenuity ... in explaining away the decision of 1894. ${ }^{69}$ For detractors, however, the Yaffe case was deeply troubling to the prospects of interventionist government. First, it took two years of appeals before the legality of the housing scheme in Yaffe was definitively settled, which, in the eyes of critics such as Ivor Jennings, was strong evidence of the deleterious effects of excessive judicial involvement in administrative decision making. ('Social reform is useless if it is not rapid,' he wrote. ${ }^{70}$ ) Second, the basic premises of certain judicial opinions in the case were regarded as excessively hostile to the very purposes of the housing legislation (which Jennings maintained was 'to remedy social evils by interfering with the rights of landowners ${ }^{71}$ ).

In a detailed analysis published in the Harvard Law Review in 1936, Jennings saw evidence in Yaffe of incorrect judicial 'presumptions' regarding parliamentary intent in housing legislation. ${ }^{72}$ For example, in the opinion of Lord Thankerton, ' $[t]$ he true principle of construction of such delegation by Parliament of its legislative function is that it confers only a limited power on the Minister, and that, unless Parliament expressly excludes the jurisdiction of the Court, the Court has the right and duty to decide whether the Minister has acted within the limits of his

$65[1930] 2$ K.B. 98.

66 [1930] 2 K.B. 133.

67 Ibid. at 148, per Lord Justice Scrutton.

68 [1931] A.C. 494.

69 Carr, Concerning English Administrative Law, supra note 39 at 48 ; see also Report of the Committee on Ministers' Powers, supra note 7 at 40 .

70 Jennings, 'Courts and Administrative Law,' supra note 47 at 447.

71 Ibid. at 451.

72 Willis also analysed the Yaffe case in detail, seeing it as the ultimate example of the 'judicial approach' to administrative law. 'Three Approaches,' supra note 5 at 67-9. Earlier in the same article Willis refers to the judicial approach as 'uncompromisingly individualistic' and 'uncompromisingly hostile. to the executive,' involving the 'application of presumptions' rooted in 'an ideal constitution in the minds of the judges.' Ibid. at 60-1. See also Willis, 'Nutshell,' supra note 9 at 17-23. 
delegated power. ${ }^{73}$ Jennings criticized similar reasoning in $R$. v. Minister of Health, ex parte Davis, in which Lord Hewart had opined that, in interpreting the powers granted to local authorities under the Housing Act of 1925, the authority would have only such powers as were 'expressed in unambiguous terms' in the statute. ${ }^{74}$ For Jennings, these and the many other cases he analysed simply represented the 'highly individualistic and conservative' outlook of the judiciary, whose bias in favour of private property and individual rights 'result[ed] in a tendency to give a restricted interpretation to the grant of powers. ${ }^{75}$

Despite the heated rhetoric on both sides of the debate over delegation and judicial review, however, there was still a basic consensus on the necessity of some form of independent legal control over the widening legislative and adjudicative discretion of government departments and subordinate authorities. Although Hewart expressed distrust for what he called the "Continental system of "Administrative Law"' (seeing it as 'profoundly repugnant ... to English ideas'), he acknowledged that it 'is at least a system. It has its Courts, its law, its hearings and adjudications, its regular and accepted procedure,' in stark contrast to the evolving 'administrative lawlessness' in England. ${ }^{76}$ Jennings, on the other hand, stated that ' $[a] d$ ministrative lawyers are as much concerned with private interests and the maintenance of just methods of control as private lawyers'; his concern, rather, was over interpretations of statutes in the ordinary courts that were 'against public policy in the interests of private property.' For Jennings, divesting the judicial courts of jurisdiction over administrative disputes was justified precisely because common law judges lacked the proper commitment to the policy goals defined in public welfare legislation. ${ }^{77}$

The real debate, therefore, was not over the necessity of independent legal control but, rather, over which judges could best balance the often conflicting interests of private rights and public welfare - those sitting on the ordinary courts, or those who were part of some hypothetical hierarchy of administrative tribunals. Willis, for his part, approached the question 'functionally' and thus squarely favoured 'the constitution of a special court' that would be 'composed of persons trained in the whole law pertaining to administration' and having 'sufficient knowledge of the legislation which is to be put into force to decide upon evidence to it

73 Yaffe, supra note 68 at 532.

74 [1929] 1 K.B. 619 at 625 (C.A.).

75 Jennings, 'Courts and Administrative Law,' supra note 47 at 434.

76 Hewart, The New Despotism, supra note 2 at 12-3.

77 As Willis puts it, 'A court's speculation about the policy of statutes dealing with "lawyer's law" is very likely to be right: about the policy of social reform statutes, of which it is almost certainly ignorant, and to which it is probably hostile, very likely to be wrong.' 'Nutshell,' supra note 9 at 4 [citations omitted]. 
what in the particular case it is best to do. ${ }^{, 78}$ The only thing 'stand [ing] in the way,' Willis asserted, was a 'misunderstood concept' that control of administrative discretion must be in the hands of an ordinary judge in a common law court. ${ }^{79}$

Given the cultural force of this 'misunderstood concept,' however, Willis recognized that the establishment of a genuinely autonomous system of administrative justice in England, or in Britain more generally, was never a real likelihood. The attachment to the ordinary courts as enforcers of the rule of law was in some sense too embedded in the constitutional history of the country for it to be abandoned in favour of a system on the continental model. Evidence of this embeddedness can be found in the 1932 report of the Committee on Ministers' Powers, set up in 1929 by the Lord Chancellor to examine the entire question of delegated legislation and judicial review in response to the contentious debate that followed the publication of The New Despotism. The committee's terms of reference, progressive critics believed, reflected too great a 'devotion to Dicey's memory, ${ }^{, 80}$ in that the terms asked for a report on 'what safeguards are desirable or necessary to secure the constitutional principles of the sovereignty of Parliament and the supremacy of the Law. ${ }^{81}$ Thus, by emphasizing 'the supremacy of the Law,' the terms of reference in some sense assumed its conclusion, at least so far as the continuation of the jurisdiction of the ordinary courts over administrative disputes was concerned. Not surprisingly, the committee, 'without hesitation, advise [d] against [the] adoption' of an autonomous system of administrative justice organically attached to the executive, on the French model. ${ }^{82}$

The Committee on Ministers' Powers issued its report unanimously, which is notable given the presence on the committee of Harold Laski, who, given his leading role among English functionalists, might perhaps have been inclined to a more radical rethinking of the structures of legal control. Instead, Laski supported the majority on preserving judicial review but inserted a 'note' in an appendix on 'the Judicial Interpretation of Statutes' as a means of qualifying or clarifying his support. His note opens by concurring that 'the interpretation of statutes which define and control the administrative process (whether local or central)' should remain the responsibility of the ordinary courts, which offered

78 'Three Approaches,' supra note 5 at 80-1.

79 Ibid. at 81.

80 Carr, Concerning English Administrative Law, supra note 39 at 27.

81 Report of the Committee on Ministers' Powers, supra note 7 at 1 . Robson laments that, as a consequence of the terms of reference, the Committee 'started life with the dead hand of Dicey on its neck.' William A. Robson, 'The Report of the Committee on Ministers' Powers' (1932) 3 Pol.Q. 351.

82 Report of the Committee on Ministers' Powers, ibid. at 110. 
'the value of the independent assessment of statutory intention. ${ }^{83}$ However, Laski also deeply criticizes the prevailing methods of statutory interpretation in the judicial courts, which had regularly invoked common law principles 'to narrow [statutory] purposes in a way which defeated the clear intention' of Parliament in adopting the legislation. ${ }^{84}$ Presaging Willis's own various contributions on the question of statutory interpretation later in the decade,${ }^{85}$ Laski calls for a method of interpretation "less analytical and more functional in character; it should seek to discover the effect of the legislative precept in action so as to give full weight to the social value it is intended to serve. ${ }^{86}$ To this end, he suggests that statutes henceforth contain a preambular 'authoritative explanation of intention ${ }^{\prime 87}$ and that, more generally, there be an 'enlargement of the sources of interpretation. ${ }^{88}$

The interpretive approach supported by Laski carried its own risks, however, notably in the extent of effective normative power it transferred to the judge, using what may well be vaguely expressed legislative purposes (or purposes that the judge simply imputes to the drafters without strong evidence) to interpret a statute in the most expansive manner possible. The danger of aggressive use of adjudication to move beyond any intent that could be reasonably attributed to the legislature was well expressed by Cecil Carr, a British expert in the development of English administrative law, in the Carpentier Lectures at Columbia University in the fall of 1940:

One eminent writer [Ivor Jennings] has challengingly stated that the whole purposes of our English Housing Acts is to remedy social evils by interfering with the rights of landowners. If the sponsors of those Acts had proclaimed that to be their object, does anyone imagine that the Acts would have been so easily passed? ${ }^{39}$

At issue, ultimately, was how far an administrative statute in its actual operation could be detached from the intent, however confused or

83 Ibid., Annex V at 135.

84 Ibid. In Laski's view, the British courts generally 'exaggerate[d] the degree to which the intention of Parliament may be discovered from the words of a statute,' but more importantly, citing Oliver Wendell Holmes, they 'under-estimate[d] the degree to which the personality of the judge ... plays a part in determining the intention he attributes to Parliament.' Ibid., citing Lochner v. New York, 198 U.S. 45, 76 (1905) (Holmes J. dissenting) (calling the personality of the judge the 'inarticulate major premise' in judicial logic).

85 See, e.g., Willis, 'Nutshell,' supra note 9.

86 Report of the Committee on Ministers' Powers, supra note 7, Annex V at 137.

87 Ibid. at 136.

88 Ibid. at 137.

89 Carr, Concerning English Administrative Law, supra note 39 at 28, citing Jennings, 'Courts and Administrative Law,' supra note 47. 
contradictory, of the legislative majority that adopted it. This was another way of asking, How much normative autonomy should the administrative body have? For the followers of Dicey, who assumed that 'the purpose of the constitution was the protection of individual rights ${ }^{90}$ - in the sense of property rights classically conceived rather than the emergent social rights in the welfare state - an administrative body should possess only so much normative autonomy as was expressly conferred under the statute, narrowly construed. For those who argued that the constitution had evolved well beyond Dicey's laissez-faire vision (Willis, Laski, Robson, and Jennings, to name a few), an administrative body should enjoy however much autonomy was functionally necessary to achieve the broadly defined social ends of the statute. The difference in these views, Carr writes,

indicates a healthy clash between political philosophies. If the progressives seek to write off Dicey as a poor old Victorian Whig who could not escape from the background of his individualistic dogmatism, his ghost might legitimately rejoin that the ideologies of his opponents were unmistakable too. ${ }^{91}$

It became the responsibility of the Committee on Ministers' Powers, in its 1932 report, to find a workable balance between these two philosophies. The committee quotes with approval a report issued the previous year noting that the most distinctive feature of modern governance in England had been the 'growing preoccupation, irrespective of party, with the management of the life of the people. ${ }^{, 92}$ This new and laudable orientation had dangers as well as merits:

It is of vital importance that the new policy, while truly promoting liberty by securing better conditions of life for the people of this country, should not, in its zeal for interference, deprive them of their initiative and independence which are the nation's most valuable assets. ${ }^{93}$

The committee focused on 'the danger incidental to the particular method by which the new policy is carried out, namely, the practice of entrusting legislative and judicial functions to the Executive. ${ }^{, 94}$ The committee's general conclusion was 'that the system of delegated legislation is both legitimate and constitutionally desirable for certain purposes,' stressing pressures on parliamentary time, the technicality of regulatory subject matters, the need for flexibility in the face of unforeseen contingencies, and, indeed, even opportunities for regulatory expe-

90 Ibid. at $27-8$.

91 Ibid. at 28.

92 Report of the Committee on Ministers' Powers, supra note 7 at 5, quoting Report of the Committee of Science and Industry, Cmd. 3897 (London: HMSO, 1931) at 4-5.

93 Report of the Committee on Ministers' Powers, ibid. at 5 [internal quotation marks omitted].

94 Ibid. 
rimentation..$^{95}$ The report rejects sweeping denunciations from the likes of Lord Hewart, finding that Hewart's criticisms, rather than destroying the case for delegation, simply demonstrated 'that there are dangers in the practice; that it is liable to abuse; and that safeguards are required. ${ }^{, 96}$

Although the committee regarded judicial safeguards as important, the report stresses above all the necessity of more effective forms of parliamentary control. Delegation 'does to some extent entail an abandonment by Parliament of its legislative functions,' the committee notes. ${ }^{97}$ Moreover, there was 'at present no effective machinery for Parliamentary control over the many regulations of a legislative character that are made every year by Ministers in pursuance of their statutory powers. ${ }^{, 98}$ Adding to the problem was the extraordinary complexity of the administrative sphere: 'Delegated legislation takes many forms,' and

[t]he limits of delegated power, the methods of Ministerial procedure, and the safeguards for the protection of the public or the preservation of Parliamentary control thus appear often to have been dictated by opportunistic considerations, peculiar to the occasion. ${ }^{99}$

The report thus calls for an overhaul of the Rules Publication Act of $1893^{100}$ to render procedures more uniform and coherent and to standardize the procedures for direct parliamentary oversight - that is, the socalled laying procedures. ${ }^{101}$

Overall, the committee emphasized the need for an augmented role for Parliament in the regulatory process, which in the first instance should be expressed through greater clarity and consistency in legislative drafting. ${ }^{102}$ This proposal was related to what the report calls the 'essen-

95 Ibid. at 51.

96 Ibid. at 54 .

97 Ibid. at 6.

98 Ibid.

99 Ibid. at 16 . To make the point, the committee published as a separate volume the memoranda submitted by government departments outlining the extraordinary variety of their legislative and adjudicative powers and the various extents to which such powers were subject to parliamentary and judicial control. See Memoranda Submitted, supra note 44.

$10056 \& 57$ Vict., c. 66.

101 Report of the Committee on Ministers' Powers, supra note 7 at 67 . These laying procedures became the favored form of parliamentary supervision over the course of the nineteenth century, although their use intensified in the twentieth. For a succinct summary of the historical development, see Sir Cecil Carr, 'Legislative Control of Administrative Rules and Regulations: II. Parliamentary Supervision in Britain' (1955) 30 N.Y.U.L.Rev. 1045 at 1045-7 ['Parliamentary Supervision in Britain'].

102 Report of the Committee on Ministers' Powers, ibid. at 58 ('that whenever legislative power is delegated, the limits of the power will be clearly defined in the statute by which it is delegated'). 
tially subordinate character of delegated legislation. ${ }^{103}$ Parliament was supreme and could therefore interfere with private rights in any way it desired, but no administrative or executive official could interfere with such rights without the sanction of Parliament. 'It follows, therefore,' the committee concludes, 'that to safeguard [this principle] the precise limits of law-making power, which Parliament intends to confer on the Minister, should always be defined in clear language by the statute which confers it. ${ }^{104}$ As a means of enforcement, the committee further suggests that,

[e]xcept where immunity from challenge is intentionally conferred, there should not be anything in the language of the statute even to suggest a doubt as to the right and duty of the Courts of Law to decide in any particular case whether the Minister has acted within the limits of his power. ${ }^{105}$

While few of the committee's proposals would actually make their way into law over the remainder of the $1930 \mathrm{~s},{ }^{106}$ the committee's report would nevertheless serve as the point of departure for post-1945 reform discussions on delegated legislative and adjudicative power in England. ${ }^{107}$ In a pragmatic fashion, the committee described the changing nature of modern governance at the national level, notably the diffusion and fragmentation of normative power among national and subnational executive and administrative bodies, as well as among public, quasipublic, and traditionally private entities. ${ }^{108}$ Following the lines of Willis's Parliamentary Powers, the committee found that the phenomenon of delegation was not inherently dangerous, but, contra Willis, this diffusion of authority did require safeguards to 'reconcile' it with the values of parliamentary sovereignty and the rule of law inherited from the past. The legal and political formula for that reconciliation, the committee suggested, would involve some combination of direct legislative oversight, ministerial responsibility, and judicial review. All these elements, working together, would best ensure that administrative officials, who enjoyed a fusion of legislative, executive, and judicial functions, remained within the scope of their 'essentially subordinate' delegated authority while

103 Ibid. at 20.

104 Ibid. at 21.

105 Ibid. at 65.

106 See Carr, Concerning English Administrative Law, supra note 39 at 175-6, for an overview.

107 See, e.g., Report from the Select Committee on Delegated Legislation, together with the Proceedings of the Committee, Minutes of Evidence and Appendices (London: HMSO, 1953) [Report from the Select Committee].

108 'Ministers of the Crown are the chief repositories of such powers,' the committee writes, 'but they are conferred also, in differing degrees upon Local Authorities, statutory corporations and companies, Universities, and representative bodies of solicitors, doctors and other professions.' Report of the Committee on Ministers' Powers supra note 7 at 4. 
acting reasonably and respecting private rights to the extent possible in the achievement of legislatively defined public ends.

\section{The post-war constitutional settlement regarding judicial review}

Britain emerged from World War II with its basic pre-war constitutional structure intact, the cornerstone of which was the theoretical supremacy and sovereignty of Parliament. Even if the cabinet had enjoyed extraordinarily broad powers during the war, this fact did little to delegitimize delegation per se, as it had in France and Germany for obvious reasons. ${ }^{109}$ As S.A. de Smith observed a decade after the war, 'After 1939 the readiness of all parties to concede wide regulatory powers to the state lowered the temperature' of the prewar controversy over delegation. ${ }^{110}$ The practice of delegation was broadly understood as a necessary means of strengthening the state in the face of the difficult tasks of national reconstruction and renewal, just as it once had been seen as essential to organizing the national defence. ${ }^{111}$ It was also conventionally understood that (at least as a political matter) Parliament itself should decide matters of 'principle' in the statute and leave only the task of filling in the 'details' to the minister concerned. ${ }^{112}$ However, the doctrine of parliamentary supremacy also meant that the task of policing the boundary between the parliamentary and the ministerial spheres would be left almost entirely to the political process (whereas in other countries it would be subject to judicial review under reinvigorated non-delegation principles). ${ }^{113}$

For the most part, debates in post-war England focused less on 'the propriety of delegation' (as they had in the inter-war period) and more on 'the mechanics of control,'114 notably through a rationalization of the

109 See Lindseth, 'Paradox,' supra note 7.

110 S.A. de Smith, 'Rule of Law,' Book Review of Rule of Law: A Study by the Inns of Court of the Conservative and Unionist Society (1955) 69 Harv.L.Rev. 396 at 398.

111 See the Emergency Powers (Defence) Acts, 1939, 2 \& 3 Geo. 6, c. 62, pursuant to which the wartime Defence Regulations were issued. As for the major post-war legislation extending these regulatory powers into peacetime, see Supplies and Services (Transitional Powers) Act, 1945, 9 \& 10 Geo. 6, c. 10; Emergency Laws (Transitional Provisions) Act, 1946, 9 \& 10 Geo. 6, c. 26; Supplies and Services (Extended Purposes) Act, 1947, 10 \& 11 Geo. 6, c. 55; and Emergency Laws (Miscellaneous Provisions) Act, 1947, 11 \& 12 Geo. 6, c. 10. The post-war Labour government also adopted legislation relating to nationalizations, the National Health Service, town and country planning, transport, and agriculture that delegated significant regulatory powers as well.

112 See Memorandum of Cecil Carr in Report from the Select Committee on Delegated Legislation, together with the Proceedings of the Committee, Minutes of Evidence and Appendices (London: HMSO, 1953) at 7-8. In fact, extraordinarily broad delegations were often made. For a useful set of examples, see ibid.

113 Lindseth, 'Paradox,' supra note 7.

114 Carr, 'Parliamentary Supervision in Britain,' supra note 101 at 1052. 
system of parliamentary oversight of delegated legislation. Although this oversight would inevitably prove imperfect, its existence suggests one important thing about the post-war administrative state in England: hierarchical control of administrative rule making by government ministers alone could not, solely on the basis of ministerial responsibility before Parliament, legitimize delegated legislative powers in democratic terms. Rather, some other form of parliamentary involvement would prove necessary to 'democratize' delegation in a manner consistent with English constitutional traditions.

Among the problems with existing mechanisms of parliamentary oversight was their seeming incoherence. The Committee on Ministers' Powers of 1932 had examined in detail the procedures for 'laying' subordinate legislation before Parliament and found that it was 'impossible to discover any rational justification for the existence of so many different forms of laying or on what principle Parliament acts in deciding which should be adopted in any particular enactment ${ }^{\prime 15}$ - mere laying, affirmative, or negative. ${ }^{116}$ The committee was further troubled by the 'extraordinary and quite illogical differences' in the time periods during which a member could make a prayer to annul under the negative procedure. ${ }^{117}$ Finally, it found confusing the variety of terms used - regulations, rules, Orders in Council - to describe the legislative instruments produced by ministers under specific enabling acts.

The Statutory Instruments Act of $1946^{118}$ was an attempt to address some of these concerns. It standardized the laying period at forty days ${ }^{119}$ and gave the descriptive title of 'statutory instruments' to all subordinate legislation, regardless of how these instruments were designated in the enabling act. ${ }^{120}$ It further provided for the numbering and publication of all statutory instruments as soon as they were made. As an additional step in rationalizing the system of publicity, subsequent regulations adopted pursuant to the act provided for the publication of an annual compendium of all instruments made the prior year, as well as of a table showing

115 Report of the Committee on Ministers' Powers, supra note 7 at 42.

116 The various laying-before procedures are summarized in ibid. at 41-2; see also Bernard Schwartz, Law and the Executive in Britain: A Comparative Study (New York: New York University Press, 1949) at 104; John E. Kersell, Parliamentary Supervision of Delegated Legislation: The United Kingdom, Australia, New Zealand and Canada (London: Stevens \& Sons, 1960) at 15-6.

117 Report of the Committee on Ministers' Powers, supra note 7 at 42 . In some cases the period was as great as $\mathbf{1 0 0}$ days or as little as twenty, but laying periods of forty, thirty-six thirty, twenty-eight, and twenty-one days were also common. In addition, the statutes varied as to whether the laying period ran only during days on which Parliament actually sat and as to whether only calendar days were included.

$1189 \& 10$ Geo. 6, c. 36; see also Statutory Instruments Regulations, 1947, S.I. 1948/1; and Statutory Instruments (Confirmatory Powers) Order, 1947, S.I. 1948/2.

119 Ss. 5 and 6.

120 S. 1 . 
the effects of any new statutory instruments on existing instruments, a particularly useful tool for practitioners. ${ }^{121}$ The act did not, however, impose a uniform laying procedure, which meant that future Parliaments would still be free to determine, on a case-by-case basis, in light of the interests concerned as well as the regulatory domain in question, the appropriate form of laying, if any.

The laying procedures were expressive of a basic premise of British public law in the immediate post-war years, that the control of delegated legislative power was at its core a political question, to be played out in the parliamentary sphere. The courts had long found that, because the laying procedures purportedly gave parliament 'full control, ${ }^{122}$ limited judicial review necessarily followed. As Lord Greene, the Master of the Rolls in the Court of Appeal, stated in 1947, 'The common law does not control Parliament, and if Parliament confers on a Minister a power to make regulations, how can the court enquire into these regulations beyond ascertaining whether they are within the power?' ${ }^{123}$ Although this passage appears in a context pertaining to ministerial oversight of local authorities, it fairly describes a more basic judicial attitude. Short of a showing that the administrative act was ultra vires, judicial deference to the minister was required because, according to the statutory directive from Parliament, 'the ultimate arbiter is the Minister himself. ${ }^{124}$ The minister, in turn, derived his authority from - and was politically responsible to - Parliament; and thus it was for Parliament, and not the courts, to develop the first line of controls over the exercise of executive and administrative power.

The courts also refused to consider whether Parliament's 'full control' in reality meant the kind of 'full scrutiny' that might truly justify a limited role of the courts (there was plenty of room for doubt in this regard).$^{125}$ Rather, the solution was again political and parliamentary, not judicial. In 1944, the House of Commons established a standing committee to scrutinize the executive's exercise of delegated legislative powers after 'some persistent back-benchers induced a previously reluctant Leader of the House' to do so. ${ }^{126}$ The Scrutiny Committee, as it was commonly

121 For a detailed discussion, along with other publications and research tools for the practitioner, see House of Commons Library Document No. 5, Access to Subordinate Legislation (London: HMSO, 1963).

122 See discussion of Lockwood, supra note 60.

123 Taylor v. Brighton Borough Council, [1947] K.B. 736 at 739.

124 Ibid. at 748-9.

125 Mitchell, 'Causes and Consequences,' supra note 32 at 101.

126 Carr, 'Parliamentary Supervision in Britain,' supra note 114 at 1049 . The Lords had established such a committee in the 1920 s, but only to examine instruments subject to the affirmative procedure. The Committee on Ministers' Powers of 1932 had recommended the establishment of standing committees in each house with the responsibility of overseeing the executive's exercise of delegated legislative powers. 
called, was not to consider the policy or the merits of an instrument (questions believed best left to the relevant minister and his subordinates), nor was it to examine the question of legal validity (believed best left to the courts). Its terms of reference nevertheless authorized it to draw the attention of the Commons to any 'unusual or unexpected use of the statutory power, ${ }^{127}$ which meant that, in practice, the committee 'found itself peeping over the fence at questions of policy, merits, and vires.' ${ }^{128}$

Still, the number of instruments reported out by the committee was generally very limited. Between the time of its establishment in 1944 and the end of the 1953-1954 session, according to the counsel to the Speaker of the House of Commons, the committee had examined 6886 instruments but had called the attention of the House to only sixty-six. ${ }^{129}$ This limited activity does not mean, however, that parliamentary scrutiny of delegated legislation played little role in British political life in the post-war years. Because any MP had the right to make a prayer for annulment (where the negative procedure applied), this presented a strategic opportunity for opposition backbenchers to harass and annoy the government. Such actions were particularly bothersome because prayers to annul were heard at the end of each day, after the close of normal business, and debates on them could last into the early morning hours. Conservative backbenchers used the tactic to great effect after the 1950 general election, when Clement Attlee's Labour government was returned with a majority of only eight. ${ }^{130}$ Labour backbenchers returned the favour after the Conservatives came to power in 1951 with a majority of only sixteen.

This sort of 'guerrilla warfare' was 'exhausting for both sides, ${ }^{, 131}$ wrote a conservative observer, and thus, by resolution of the House of Commons, a Select Committee on Delegated Legislation was established in December 1952 to consider reforms. ${ }^{132}$ Like the Committee on Ministers' Powers of 1932, this body was designed to be bipartisan, including members recognized primarily for their breadth of knowledge about both

127 The full terms of reference are reprinted in ibid. at 1050, n.21.

128 Ibid. at 1050.

129 Ibid.

130 Attlee later recalled that '[i]t was not pleasant to have Members coming from hospital at the risk of their lives to prevent a defeat in the House' on a prayer to annul a statutory instrument. Clement Attlee, As It Happened (London: Heinemann, 1954) at 206.

131 C.K Allen, Law and Orders: An Inquiry into the Nature and Scope of Delegated Legislation and Executive Powers in English Law, 2d ed. (London: Stevens \& Sons, 1956) at 188 [Law and Orders].

132 The terms of reference can be found in Report from the Select Committee, supra note 107 at ii. 
executive and legislative spheres. ${ }^{133}$ It also followed the 1932 example in another, perhaps unintended, respect: its report actually led to very few reforms (apart from a rule cutting off debate on prayers at 11:30 p.m.). Rather, the Select Committee's basic finding could perhaps be summarized in the words of one of its members, who called the existing procedures for parliamentary control 'quite illogical and everything else, but ... not too bad. ${ }^{134}$

Thus, as the 1950s proceeded, the public law debate in England shifted its focus from delegated legislative to delegated adjudicative power, as well as to the nature and scope of judicial review, which in many respects had been the more contentious issues in the inter-war period. In the immediate post-war years, English academic commentators often wrote with embarrassment of the state of their country's system of administrative justice. On the one hand, the prevailing mindset was still said to suffer from the residual influence of Dicey's inaccurate depiction of the administrative law 'as a misfortune inflicted upon the benighted folk across the Channel. ${ }^{, 135}$ On the other hand, there was the reality of 'a plethora of ad hoc tribunals,' appointed by ministers, not necessarily sitting in public, sometimes excluding legal representation, with often highly informal procedural and evidentiary rules, not always bound to provide reasons for decisions, and not necessarily subject to appeal to a court on questions of law. ${ }^{136}$

Unfavourable comparisons were made not only with the French system of droit administratif but also with the situation that prevailed in the United States, Britain's common law confrère, which had passed a farreaching Administrative Procedure Act in $1946 .{ }^{137}$ As Harry Street wrote in the Yale Law Joumal in 1950: 'American administrative law is so much more developed than the British that there is little for an American lawyer to learn from the British experience - except to be on guard against a weakening of judicial control. Cannot Marshall Plan Aid include "administrative law"? 138 Indeed, the widely recognized inadequacies of the British system of administrative justice in the late 1940s and

133 Three members were ex-Secretaries of State and three were former junior ministers. Carr, 'Parliamentary Supervision in Britain,' supra note 114 at 1052.

134 Quoted in Allen, Law and Orders, supra note 131 at 191.

135 De Smith, 'Rule of Law,' supra note 110 at 398.

136 Ibid. at 397.

137 Pub. L. No. 79-404, 60 Stat. 237-44, codified at 5 U.S.C. $\$ \S 551-9$ (1946). For a comparison by an English commentator, written in the immediate post-war period, looking at both the French and American systems (with explicit reference to the rights of judicial review under the Administrative Procedure Act), see Marguerite A. Sieghart, Government by Decree: A Comparative Study of the History of the Ordinance in English and French Law (London: Stevens \& Sons, 1950) at 317.

138 H. Street, Book Review of Law and the Executive in Britain: A Comparative Study by Bernard Schwartz (1950) 59 Yale L.J. 590 at 593. 
early 1950 s provided the terrain on which antagonists from the inter-war period could now find a point of agreement. ${ }^{139}$

The state of English administrative justice became a heated point of public controversy after 1954 as a consequence of the so-called Crichel Down Affair, which involved a dispute over the Ministry of Agriculture's handling of a parcel of land that it had compulsorily purchased in 1937. The details of this affair need not concern us here. ${ }^{140}$ Suffice it to say that, although the affair did not itself directly involve an administrative tribunal, it did expose problems relating to administrative secrecy, organizational complexity, the lack of clear lines of authority, and opportunities for unfairness that these factors created (all problems said to afflict the system of administrative justice as well). Moreover, the affair exposed the limitations of the doctrine of ministerial responsibility: although the minister in charge resigned as a consequence of the affair, this was broadly regarded as 'a severe and perhaps excessive application of the constitutional doctrine, ${ }^{141}$ since it was understood that no minister could directly supervise the activities of the vast number of subordinates implementing programs and exercising discretionary power in the field.

To quell the public outcry that flowed from the affair, the British government established a Committee on Administrative Tribunals and Enquiries in November 1955 to examine the question of administrative justice. Known as the Franks Committee (after its chairman), this body took evidence over the course of 1956 and early 1957 and issued its report in July of that year. ${ }^{142}$ The report begins by describing the political reasons for the expansion of administrative adjudicative power. 'Since the war,' it states, 'the British electorate has chosen Governments which

139 On the right, see C.K. Allen, 'Foreword' in Marguerite A. Sieghart, Government by Decree: A Comparative Study of the History of the Ordinance in English and French Law (London: Stevens \& Sons, 1950) $\mathrm{x}$ at xiii, in which Allen concludes that 'the time has come, in view of the great and increasing pressure of administrative problems,' to establish a system of administrative tribunals on the French model to hear administrative disputes. This suggestion was gladly welcomed on the left by William Robson, who wrote in 1951 that Allen was simply calling for 'reforms in the direction I have long regarded as essential.' See William A. Robson, Justice and Administrative Law: A Study of the British Constitution, 3d ed. (London: Stevens \& Sons, 1951) at 465. For a similar proposal, this time again from the right, see Inns of Court Conservative and Unionist Society, Rule of Law: A Study by the Inns of Court Conservative and Unionist Society (London: Conservative Political Centre, 1955).

140 For a contemporary overview see J.A.G. Griffith, 'The Crichel Down Affair' (1955) 18 Mod.L.Rev. 557; see also Allen, Law and Orders, supra note 131 at 344-6.

141 Ibid. at 340.

142 Report of the Committee on Administrative Tribunals and Enquiries, Cmd. 218 (London: HMSO, 1957); Committee on Administrative Tribunals and Enquiries, Minutes of Evidence (London: HMSO, 1956-1957); Committee on Administrative Tribunals and Enquiries, Memoranda Submitted by Govermment Departments, 6 vols. (London: HMSO, 1956). 
accepted general responsibilities for the provision of extended social services and for the broad management of the economy.' ${ }^{143}$ These expanded responsibilities required the passage of legislation that applied 'detailed schemes to the whole or large classes of the community (for example national insurance) or [placed] on a Minister and other authorities a general duty to provide a service (for example education or health). ${ }^{144}$ The terms of such public welfare legislation, however, were 'rarely sufficient ... to achieve all [their] objects,' thus necessitating the delegation of both legislative and adjudicative powers to the executive. ${ }^{145}$

Specifically as to adjudicative powers, the committee found that it was now time 'to consider afresh the procedures by which the rights of individual citizens can be harmonized with wider public interests. ${ }^{146}$ The report notes that the resolution of disputes regarding administrative programs in England had never been entrusted exclusively or even largely to the courts of law, the traditional dispensers of justice. The report agrees with the Committee on Ministers' Powers of 1932 that administrative 'tribunals have certain characteristics which give them advantage over the courts. These are cheapness, accessibility, freedom from technicality, expedition and expert knowledge of their particular subject. ${ }^{, 47}$ The general question before the committee, however, was how best to characterize these tribunals: Are they 'part of the machinery of justice,' or are they 'mere administrative expedients'? ${ }^{148}$ This question was at the core of the constitutional struggle to stabilize administrative governance in England in the first half of the twentieth century. Despite the arguments of government witnesses 'that tribunals should properly be regarded as part of the machinery of administration, for which the Government must retain close and continuing responsibility,' the committee emphatically found to the contrary. Tribunals were in fact 'part of the machinery provided by Parliament for adjudication,' responsible, along with the courts, for the enforcement of the rule of law. ${ }^{149}$

The reforms resulting from the issuance of the Franks Committee's report (notably the passage of the Tribunals and Inquiries Act of $1958^{150}$ ) built directly on this premise. Although constituted as part of the administrative sphere and structured accordingly, administrative tribunals still had a basic obligation to dispense justice in an independent fashion. The

143 Report of the Committee on Administrative Tribunals and Enquiries, supra note 142 at 2.

144 Ibid.

145 Ibid.

146 Ibid.

147 Ibid. at 9.

148 Bernard Schwartz \& H.W.R. Wade, Legal Control of Government: Administrative Law in Britain and the United States (Oxford: Clarendon Press, 1972) at 151 [Legal Control].

149 Report of the Committee on Administrative Tribunals and Enquiries, supra note 142 at 9.

150 Supra note 29. 
committee placed a great deal of emphasis on the fact that the term 'tribunal,' as it appeared in the statutes, indicated intent on the part of Parliament 'for a decision outside and independent of the Department concerned. ${ }^{\prime 51}$ The Tribunals and Inquiries Act thus established a Council on Tribunals with broad consultative and review functions over the procedures and constitution of tribunals in the administrative sphere. ${ }^{152}$ Although the act itself did not specify a uniform code of tribunal procedure, the work of the Council on Tribunals over the subsequent decade established 'a much clearer standard' of what was minimally necessarily consistent with fairness. ${ }^{153}$ This generally came to include a public hearing, the right to legal representation, the right to call witnesses, adversarial procedure, and the full disclosure of relevant documents. Importantly, the act itself provided for extended rights of appeal to judicial courts (reflective of the fundamentally subordinate character of these tribunals on questions of law) ${ }^{154}$ as well as a requirement that tribunals publicly provide reasons for their decisions (essential to effective judicial review)..$^{155}$

The Franks Committee report and the passage of the Tribunals and Inquiries Act of 1958 constituted a key turning point in the post-war evolution of administrative law in England. Although it is difficult to establish a direct causal relationship, the act arguably served as a 'catalyst for reform' not merely within the administrative sphere but also within the courts of law, which became noticeably 'more active and enterprising' after $1958{ }^{156} \mathrm{~A}$ new era in the development of administrative law jurisprudence ensued, ending the extreme deference of the courts to the

151 Report of the Committee on Administrative Tribunals and Enquiries, supra note 142 at 9 . This reasoning is reminiscent of the evolving thinking regarding French administrative justice in the nineteenth century, in which the juridiction administrative became distinct from the administration active. It had been a basic tenet of French administrative law that juger l'administration, c'est encore administrer - to judge the administration is still to administer. However, as a leading commentator and member of the Conseil d'état concluded in 1852, 'juger, c'est juger' - to judge is to judge - meaning that parties to administrative disputes should be entitled to a procedurally fair hearing by an independent administrative judge, even if that judge is, formally speaking, attached to the executive. See Alexandre-François Vivien, Etudes administratives, 2d. ed (Paris: Guillaumin, 1852) at 130 . For the definitive history of the separation of administrative justice from active administration in France over the course of the nineteenth century, see Jacques Chevallier, L'Elaboration historique du principe de séparation de la juridiction administrative et de l'administration active (Paris: LGDJ, 1970). This history is also briefly traced in Lindseth, 'Always Embedded,' supra note 32.

152 A detailed analysis of the act can be found in Appendix 1 to S.A. de Smith, Judicial Review of Administrative Action (London: Stevens \& Sons, 1959) at 459-65.

153 Schwartz \& Wade, Legal Control, supra note 148 at 153.

154 At s. 9.

155 At s. 12.

156 Schwartz \& Wade, Legal Control, supra note 148 at 5. 
political imperatives of Parliament and the government in the immediate post-war decade. This attitude had led to a series of disturbing precedents regarding the limited application of principles of procedural fairness ('natural justice'), ${ }^{157}$ deference to the discretionary powers of the administration, ${ }^{158}$ and a broad reading of statutory provisions precluding judicial review. ${ }^{159}$ Over the decade following the passage of the Tribunals and Inquiries Act, the courts would reinvigorate the application of principles of natural justice, ${ }^{160}$ impose much stricter judicial limits on ministerial discretion, ${ }^{161}$ give a much more narrow reading to privative clauses, ${ }^{162}$ and more generally use the doctrine of ultra vires to review a broad range of alleged administrative illegalities. ${ }^{163}$

Although one could fairly say that this sort of judicial activism in the face of administrative power was precisely what Lord Hewart was calling for when he published The New Despotism in 1929, there were several major differences in the political and legal environment in the late 1950s and early 1960 s as compared to three decades earlier. After World War II, few in the judiciary any longer seriously questioned (at least openly) the right of the state to intervene actively in social and economic affairs, even if this intervention conflicted with property rights. ${ }^{164}$ Consequently, the greater activism of the English courts at the beginning of the 1960s was not seen as a conservative attempt to protect the interests of private property; rather, the courts were simply seeking the 'new balance between private right and public advantage' that the Franks Committee

157 Nakuda Ali v. Jayaratne, [1951] A.C. 66; $R$. v. Metropolitan Police Commissioner ex parte Parker, [1953] 1 W.L.R. 1150. In these cases, the courts refused to apply principles of natural justice to a cancellation of a licence even though the holder's livelihood depended on it.

158 See, e.g., Robinson v. Minister of Town and Country Planning, [1947] K.B. 702.

159 See, e.g., Woollett v. Ministry of Agriculture and Fisheries, [1955] 1 Q.B. 103.

160 Ridge v. Baldwin, [1964] A.C. 40.

161 Commissioners of Customs and Excise v. Cure E $\mathcal{F}^{2}$ Deeley Ltd., [1962] 1 Q.B. 340.

162 Anisminic Ltd. v. Foreign Compensation Commission, [1969] 2 A.C. 147.

163 For a summary, see Schwartz \& Wade, Legal Control, supra note 148 at 299. For a detailed historical consideration of increasing judicial activism in the early 1960 s, see John Griffith, Judicial Politics, supra note 56 at c. 4.

164 As Willis himself describes in his review of Denning's Freedom under the Law (1949),

Lord Justice.Denning dismisses as unfortunate the vigour with which the nineteenth century judges protected freedom of property and freedom of contract and welcomes the intervention of Parliament to force those who provide essential supplies and services to provide adequate and efficient service at reasonable charges and to put on the state the positive responsibility of seeing that everyone is provided with the necessities of life.

Review of Denning, Freedom, supra note 9 at 415 . Willis expresses relief that 'here at last was a judge who was not prepared to follow the strict party line of Lord Hewart or Dr. C.K. Allen....' Ibid. Willis may not have believed it, but arguably Denning's position was indicative of the broader English judiciary in the post-war period. 
had argued was necessary to achieve both 'fair play for the individual and efficiency of administration. ${ }^{, 65}$ In other words, in the constitutional settlement over judicial review that ultimately took hold in England, the role of the courts was not to impede administrative power but to legitimize it. The courts served as a 'commitment mechanism' (again, to use game-theoretical language) to ensure that the administrative state observed certain basic norms of a constitutional nature, such as natural justice, while also respecting the boundary between intra and ultra vires as established by the enabling legislation itself.

There was also a specifically functional reason for the increase in judicial controls in the post-war constitutional settlement: given the growing regulatory and interventionist ambitions of the welfare state, administrative agents who operated under the auspices of the executive came to enjoy, as a consequence of organizational complexity (if not also of formal legal right), a significant degree of effective independence. This 'agency autonomy' undermined the effectiveness of hierarchical political control by ministers or by Parliament - that is, the democratically legitimate 'principals' in the system - and thus created the need for an alternative kind of commitment mechanism to ensure compliance with the legislative and constitutional requirements. Judicial controls served this functional purpose, even as the activities of the courts were normally rationalized in terms of the protection of individual rights, consistent with the constitutionalist ethos of the post-war period. Administrative litigation was a means by which Parliament could enlist judicial power and private interests in the task of controlling the normative autonomy of the executive and administrative sphere, and thereby indirectly assert the legislature's own superior democratic legitimacy in the construction of the welfare state.

IV Conclusion:

Willis and the function of judicial review in the administrative state

Willis's overheated critique of the McRuer Report in 1968 - exemplified by his sarcastic suggestion that 'the Commission might just as well go the whole hog and recommend that all the deciding authorities of whatever nature be brought within the ordinary court system ${ }^{, 66}$ (something very far from anything the Commission had actually recommended) - seems to suggest an inability to move beyond the English battle lines of the 1920s and 1930s. Statements in 'Canadian Administrative Law in Retrospect' in 1974 are to similar effect, particularly the derisive references to 'the parables sometimes drawn from the Stuart period by some twentieth-

165 Report of the Committee on Administrative Tribunals and Enquiries, supra note 148 at 2.

166 Willis, 'Lawyers' Values,' supra note 9 at 360. 
century judges,' or to what Willis called the 'theology' of modern administrative law (but which 'the devotees thereof would certainly call "enduring values"'). Willis also tellingly laments the emergence of 'a number of currently fashionable cults and the damage they may do to effective government if they are allowed to infiltrate too deeply into the procedural part of administrative law. ${ }^{167}$ These include:

the cult of the 'individual' and claims by prisoners in penitentiaries, complaining of their treatment there or applying for parole, to a formal 'right to be heard'; the cult of 'openness' and claims by the press to the right to dig into confidential government files; the cult of 'participatory democracy' and claims by 'concerned' busybodies to the right to be allowed to take court proceedings to curb, say, alleged illegal pollution or alleged dereliction of duty by the police. ${ }^{168}$

This is powerful, even inflammatory, language. It is also perhaps misleading, however, as to the extent to which Willis's views represented unreconstructed hostility to the then-current directions in administrativelaw doctrine. Other writings of Willis from the post-war decades suggest that he, too, recognized that judicial review could serve an important control function in the administrative state - only one significantly more limited than what the administrative law 'theologians' normally deemed advisable. For example, in his 1959 commentary on the implications of the Franks Committee's report for Canadian law, Willis states that 'the courts should never be deprived of their historic power to require deciding authorities to approach the matter before them in a fairminded way and with a fair procedure,' calling this a 'quasi-constitutional guarantee ... against the possibility of arbitrary action. ${ }^{.169} \mathrm{He}$ objected only to review over questions of law, or, more particularly, statutory interpretation, repeating his fears from the 1930s that when courts 'interpret' statutes, what they usually do is simply 'pour their views into ... the vague statutory standard [that] the board was set up to administer [and] thereby dictate to the board what any layman will recognize as policy. ${ }^{170}$

Unfortunately Willis does not elaborate on these arguments, but an American would immediately recognize in them features of our system of administrative law as it has evolved over the last three decades, notably

167 Willis, 'Retrospect,' supra note 9 at 229.

168 Ibid.

169 Willis, 'Canadian Implications,' supra note 9 at 54. However, David Dyzenhaus's contribution to this volume suggests scepticism toward such stray statements in view of the much more pervasive hostility to judicial review that one finds throughout Willis's writings, which Dyzenhaus sees as evidence of Willis's fundamental rejection of the 'logic of the rule of law.' David Dyzenhaus, 'The logic of the rule of law: Lessons from Willis' (2005) 55 U.T.L.J. 691.

170 Willis, ibid. at 55; see also Willis, 'Administrator as Judge,' supra note 9 at 436 . 
our judicially enforced guarantees of 'reasoned decisionmaking' under the 'arbitrary and capricious' clause of the Administrative Procedure Act, ${ }^{171}$ as well as judicial deference to agency statutory interpretations under the Chevron doctrine. ${ }^{172}$ The similar constraints advocated by Willis were undoubtedly motivated by a desire to keep courts out of policy making, but the American experience over the last several decades suggests that even these constraints leave the courts ample room, under the guise of legal control, to second-guess policy making in the administrative sphere.

Not only is this unsurprising, it well may reflect a deeper functional truth: that legislatures would not so freely delegate normative power and popular opinion would not tolerate such broad delegations without this functional background constraint securely in place. One can only imagine what Willis (who famously tried to 'talk law with a ... political science accent ${ }^{173}$ ) would make of more recent work in political science that outlines a positive political theory of judicial review precisely as a principal-agent control on delegated normative power. Rather than deriding judicial enforcement of transparency and participation rights as 'cults' to be opposed, this work recognizes that judicial enforcement of such rights may serve as an indirect means by which national legislatures monitor the activities of their national executives and subordinate bureaucratic officials. From a principal-agent perspective, judicially enforceable transparency and participation rights in the administrative sphere act as forms of 'fire-alarm oversight' - that is, as a legislative harnessing of private interests and the courts in the broader project of reducing the inevitable agency autonomy that flows from delegation. Judicial review in this way operates in conjunction with hierarchical political oversight - 'police patrols' - exercised by the democratically legitimate political principals in the legislature or at the summit of the executive (chief executives, cabinet secretaries, or their immediate appointees). ${ }^{174}$

Was Willis, who claimed to be a "what actually happens man, ${ }^{, 75}$ so bound up in his own normative critique of seemingly retrograde, 'antibureaucratic' judicial attitudes left over from the inter-war period (whether they belonged to Hewart or-purportedly - McRuer) that he failed to see the potential for a functionalist defence of broad forms of

1715 U.S.C. $\$ 706(2)(A)$.

172 Chevron U.S.A. v. Natural Resources Defense Council, 467 U.S. 837 (1984).

173 Willis, 'Retrospect,' supra note 9 at 227

174 See Matthew McCubbins \& Thomas Schwartz, 'Congressional Oversight Overlooked: Police Patrols versus Fire Alarms' in Matthew McCubbins \& Terry Sullivan, eds., Congress: Structure and Policy (New York: Cambridge University Press, 1987) 426 at 426-34.

175 Willis, 'Retrospect,' supra note 9 at 225. 
judicial review? I cannot say. What it does seem fair to say, however, is that Willis, in his fixation on the battles of the 1930s, had a very limited sense of the appropriate types of controls in the administrative state. In Willis's estimation, the essential 'safeguards are not [provided by] the courts but [by] question time in the House of Commons, an opposition press, pressure groups and last, but not least, the good sense and decency of the officials. ${ }^{176}$ In light of experiences like the Crichel Down Affair, however, there was an understandable concern over an excessively autonomous bureaucratic apparatus, ${ }^{177}$ as well as over the adequacy of hierarchical political controls, standing alone, to control that autonomy.

This functional explanation for the persistence of judicial review in the administrative state, although in many respects persuasive, is incomplete, in my view. It is, rather, necessary to return to a point I stressed at the beginning of this article: the impact of historical political culture and its dialectical relationship to the functional adaptation of structures of governance in the twentieth century.. To fully appreciate historical change in the administrative state, one must appreciate how changing structures of governance were 'experienced' in light of historically rooted conceptions of legitimacy and, in turn, how that experience motivated the evolution of administrative law - that is, its 'reconciliation' with the past. Willis recognized, with frustration, that conceptions of legal legitimacy inherited from the past could become social and political realities 'by prescription, and so, alas, at present ineradicable. ${ }^{178}$ But he never fully accepted the implications of this insight. He saw such historical conceptions of legal legitimacy rooted in judicial review only as 'misunderstood' obstacles to the proper structural-functional evolution of administrative structures. ${ }^{179}$

In the end, then, maybe it was Willis who did not understand. What he called the 'long-dead eighteenth-century past ${ }^{180}$ was neither dead nor even really past. A pure, 'functional' evolution in administrative structures without 'refraction' through a historically contingent cultural 'experience' was an impossibility. ${ }^{181}$ Indeed, Willis elsewhere states that

176 Willis, Review of Denning, Freedom, supra note 9 at 416.

177 This distrust is likely well placed, no matter how 'decent' the civil servants turn out to be. Of particular relevance here are the insights of modern cognitive psychology on decision-making biases in large-scale organizations. See, e.g., Jeffrey J. Rachlinski \& Cynthia R. Farina, 'Cognitive Psychology and Optimal Government Design' (2002) 87 Cornell L.Rev. 549.

178 Willis, Review of Jennings, Cabinet Government, supra note 9 at 581 .

179 In calling for the creation of a special court of review of administrative action, something that Willis believed was functionally necessary, he states, 'Nothing stands in the way but a misunderstood concept.' 'Three Approaches,' supra note 5 at 81 .

180 Willis, 'Retrospect,' supra note 9 at 245.

181 See Thompson, 'History and Anthropology,' supra note 28, and accompanying text. 
historical-cultural conceptions of legitimacy 'crystallize in vivid, even if partially inaccurate, form the spirit of tried national institutions. ${ }^{182}$ The English effort to reconcile administrative governance and historical conceptions of constitutional democracy and the rule of law in the postwar decades could not ultimately break from these 'tried national institutions' (not just Parliament but also the ordinary courts) because the prevailing political culture would not permit it.

The reconciliation of the old and the new that Willis saw as problematic - the 'seeing [of] likeness in unlike things ${ }^{\text {'183 }}$ - became possible only because English administrative law retained forms of control rooted not just in Parliament and the government but also in the ordinary courts. In this way, the post-war constitutional settlement in England preserved some semblance of both parliamentary sovereignty and the rule of law. It was this combination of political and judicial control mechanisms - this 'reconciliation' with the past - that made it possible for the English people to experience the new structures of administrative governance as 'democratic' and 'constitutional' in a historically recognizable sense.

182 Willis, 'Three Approaches,' supra note 5 at 70.

183 Willis, Review of Jennings, Cabinet Government, supra note 9 at 581 . 


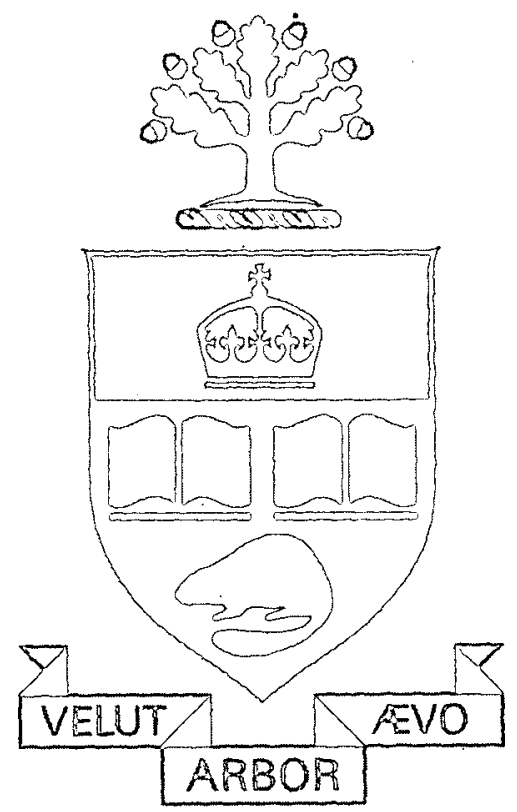

